\title{
Resource use efficiency of kinnow production in North- Western Himalayas: An economic study from Himachal Pradesh
}

\author{
Raj Rani Sharma ${ }^{1}$ and Sanjeev Kumar* \\ Department of Social Sciences, Dr. Y.S. Parmar University of Horticulture and Forestry, \\ Nauni, Solan (H.P.) India (Email: sharmask93@ rediffmail.com)
}

\begin{abstract}
The Himalayan region extends all along the Northern boundary of India. Traditionally, agriculture on hills was practiced on a subsistence basis but, with the development of means of transport, storage facilities and other infrastructure, hill agriculture has become commercial in character. The present study has been carried out in Indora and Nurpur blocks of Kangra district of Himachal Pradesh which fall in North-Western Himalayan region of India. A sample of 100 kinnow growers was drawn for the present study using multistage sampling technique. The results of the study revealed that on overall farms, 89 per cent of total variation in kinnow production was explained by independent variables. Human labour, FYM and fertilizer were under-utilized resources on overall farms and more use of these inputs will increase the output significantly. Among different categories of farms, the regression co-efficient for human labour was positive and significant on medium $(0.621)$ and large farms $(0.399)$ while fertilizerwas positively significant on all categories of farms. The regression co-efficient value for FYM was positively significant on small (0.445) and medium farms (0.474) and regression co-efficient for plant protection chemicals was found significant only on large category farms (0.158). The MVP value for human labour (1.327), FYM (3.526) and fertilizer (4.527) on overall farms revealed that by increasing the use of these inputs by $24.64,71.63$ and 77.91 per cent, respectively, the profit would be increased. The findings of the study clearly showed that these resources were underutilized by the farmers in the study area and optimum use of these resources would definitely increase the returns of kinnow growers in the study area.
\end{abstract}

Key Words : Agriculture, Multistage sampling, Regression co-efficient, Returns

View Point Article : Sharma, Raj Rani and Kumar, Sanjeev (2019). Resource use efficiency of kinnow production in North-Western Himalayas: An economic study from Himachal Pradesh. Internat. J. agric. Sci., 15 (1) : 156-162, DOI:10.15740/HAS/IJAS/15.1/156-162. Copyright@2019: Hind Agri-Horticultural Society.

Article History : Received : 09.11.2018; Revised : 14.12.2018; Accepted : 20.12.2018

\footnotetext{
* Author for correspondence:

${ }^{1}$ University Institute of Agricultural Sciences, Chandigarh University, Chandigarh (Punjab) India
} 